\title{
Fish passage post-construction issues: analysis of distribution, attraction and passage efficiency metrics at the Baguari Dam fish ladder to
}

\section{approach the problem}

\author{
Luiz Gustavo Martins da Silva ${ }^{1}$, Lorena Bettinelli Nogueira ${ }^{2}$, Bruno Pereira Maia ${ }^{2,3}$ and \\ Lucas Borges de Resende ${ }^{2}$
}

Fish passages are considered the oldest management tool used to minimize the impact of blocking fish migratory routes by hydroelectric power plants. However, fish passages are being installed without specific criteria in Brazil, with severe consequences to the conservation of the local fish fauna. Therefore, basic data gathered for fish passages already constructed could contribute to define operational rules, in addition to offer subsidies to decision-making and design of future facilities. Thus, the fish ladder of Baguari Dam was evaluated regarding temporal distribution, attraction, and ascension of the local fish fauna. A total of 20 fish samples were conducted immediately downstream of the dam and inside the fish ladder, from January 2010 to June 2011. Seasonal variation in fish abundance and richness was registered below the dam and inside the passage, with higher number of migratory fish in the reproductive season (Kruskall-Wallis, $p=0.04$ and $p=0.05$ ). Furthermore, higher concentration of migratory allochthonous and non-migratory species was registered for the spill bay (Wilcoxon, $\mathrm{p}=0.009$ and $\mathrm{p}=0.006$ ) compared to the tailrace, where the fish ladder entrance is located. This result suggests low efficiency of the attraction system of the mechanism during the reproductive period. Once entering the fish ladder, migratory species apparently ascend the facility due to the similar distribution throughout different stretches. Generally, the results showed that an operational rule for the Baguari Dam fish ladder should consider running the facility only during the reproductive period, unless the objectives of the passage are well defined. The attraction system must be more precisely evaluated, using technologies such as radiotelemetry. Similarly, fish ascension also should be better analyzed to evaluate the time spent to ascend and its influence in the reproductive biology of the species using the ladder. Pit-tag system could be used to approach this analysis. It is expected that the discussion of these results would be useful for companies of the energy sector and for environmental agencies in Brazil, subsidizing decisions related to the management of fish passages already installed and to the construction of new facilities in the country.

As passagens ou sistemas de transposição de peixes são uma das ferramentas de manejo mais antigas utilizadas para minimizar o impacto do bloqueio de rota migratória de peixes pela implantação de barragens. Todavia, sua implantação tem sido realizada sem muito critério no Brasil, trazendo consequências muitas vezes graves à conservação da ictiofauna local. Por essa razão, dados básicos obtidos para as passagens de peixes em funcionamento podem contribuir para definição de sua regra operativa, além de subsidiar tomada de decisões e o design de futuros sistemas. Assim, a escada de peixes da UHE Baguari foi avaliada quanto à distribuição temporal, atração e subida da ictiofauna local. Foram realizadas 20 amostragens a jusante da barragem e no interior da escada de peixes entre janeiro de 2010 a junho de 2011. Observou-se variação sazonal na distribuição e riqueza de espécies de peixes a jusante da barragem e dentro da escada, sendo que as espécies migradoras foram registradas em maior abundância durante o período reprodutivo (Kruskall-Wallis, $p=0,04 \mathrm{e} \mathrm{p}=0,05$ ). Além disso, nesse mesmo período, maior concentração das espécies migradoras alóctones e não migradoras foi registrada para a bacia de dissipação da barragem (Wilcoxon, $\mathrm{p}=0,009$ e $\mathrm{p}=0,006$ ) quando comparado ao canal de fuga, local onde se encontra a entrada da escada. Isso sugere que a eficiência do sistema de atração do mecanismo não seja a esperada nesse período. Uma vez dentro da escada, aparentemente as espécies migradoras percorrem todo o mecanismo, distribuindo-se de forma similar ao longo de sua extensão. Em geral, os resultados obtidos demonstram que, aparentemente, a regra operativa da escada deva indicar seu

\footnotetext{
${ }^{1}$ Universidade Federal de São João del Rei (UFSJ), Programa de pós-graduação em Tecnologias para Desenvolvimento Sustentável (PPGTDS), DTECH/CAP, Rodovia MG 443, Km7, 36420-000 Ouro Branco, MG, Brazil. luizsilva@ufsj.edu.br

${ }^{2}$ Biotec Soluções Ambientais Ltda, Rua Raul Hanriot, 123 Apto 102, 30240-430 Belo Horizonte, MG, Brazil.

${ }^{3}$ Centro Universitário UNA, Câmpus Guajajaras, Rua Guajajaras, 175, Centro, 30180-000 Belo Horizonte, MG, Brazil.
} 
funcionamento apenas no período reprodutivo, ao menos até que os objetivos da transposição de peixes na UHE Baguari sejam de fato definidos. Já o sistema de atração da escada deverá ser avaliado de forma mais precisa, utilizando-se tecnologias como radiotelemetria. Da mesma forma, a subida dos peixes pela escada deve ser melhor analisada para se avaliar o tempo gasto e a influência desse período sobre a biologia reprodutiva dos peixes. O sistema de Pit-tag pode ser utilizado para realizar essa análise. Espera-se que a discussão das informações obtidas no presente trabalho possa ser utilizada pelas empresas do setor elétrico e órgãos ambientais para subsidiar decisões relacionadas ao manejo de sistemas de transposição de peixes já em funcionamento e à construção de novos empreendimentos.

Key words: Fishway, Migratory species, Operational rule, Seasonality,Vertical-slot.

\section{Introduction}

Currently Brazil is facing an important development of the economy which increases production, consumption and the demand for basic inputs. Among these inputs electrical energy demand had increased significantly. Considering that $85.6 \%$ of the electrical energy produced in Brazil comes from hydropower generation (ANEEL, 2008), the greater the demand for electrical energy the more dams are constructed throughout the country. Recent estimates had indicated that over 700 dams were constructed in Brazil (Agostinho et al., 2007a), mostly in the southern and southeastern regions. At Minas Gerais State, a great hydroelectrical potential led the state to an expansion of hydropower production since the 1950's and the São Francisco, Grande, Paranaíba, and Doce River basins were the most affected by dam construction (Drummond et al., 2005).

The negative effects of damming rivers had been extensively discussed in the literature (Jackson \& Marmulla, 2001; Gehrke et al., 2002; Schilt, 2002; review in Schilt, 2007). Those effects vary from changes in the fluvial geomorphology altering erosion, transport and deposition of sediment to species diversity and abundance reduction (Schilt, 2007). Accordingly, dams constitute an obstruction to the movements of migratory fish species (Pelicice \& Agostinho, 2007) fragmenting the aquatic environment and blocking the accessibility to critical habitats such as reproductive sites (Fernandez et al., 2007b). Therefore, blockage of migratory pathways and consequent reduction in life-cycle success could eliminate diadromous and potamodromous species from different river basins (Agostinho et al., 2005; Okada et al., 2005; Williams et al., 2011).

In Brazil, most of the migratory species are potamodromous and locally known as 'piracema' fishes (Godinho \& Kynard, 2008) figuring among the most important species commercialy and recreationally. Although movements of many particular species of 'piracema' fishes is still poorly known (Carolsfeld et al., 2003), Godinho \& Kynard (2008) developed a conceptual model for all life stages showing a complex migration pattern. Generally, the 'piracema' fishes exhibit seasonal movements involving upstream migration of spawning adults during the flood and post-spawning downstream migration, including juvenile migration in both ways (Godoy, 1959; Alves et al., 2007a; Godinho \& Kynard, 2006; Godinho et al., 2007). Attempting to maintain upstream displacements of fish and reduce population decline where migratory routes were obstructed by dams, Brazilian authorities had incorporated fish ladders as a management tool to protect and recover fish stocks becoming popular among managers, politicians and the general public (Pelicice \& Agostinho, 2007).

Fish ladders are an open or closed channel with a small slope where hydraulic energy is dissipated by weirs to allow fish to pass through the dam (Santos et al., 2007). It is considered to be the oldest management strategy adopted in Brazil to reduce the negative effects of damming rivers over migratory species, although its efficiency to maintain viable populations was rarely assessed (Pompeu et al., 2012).

Therefore, the effectiveness of fish passages in Brazil as a conservation tool is still controversial. Recent studies showed that depending on the location of a dam related to critical habitats such as spawning and rearing, fish passages could play a role as ecological traps (Pelicice \& Agostinho, 2007), or as sourcesink dynamics (Godinho \& Kynard, 2008). For Pompeu et al. (2012) both cases should consider that the principal objective of a fish passage is to maintain the recruitment of wild stocks, although a secondary objective (e.g. artificial stocking) could be related to the source-sink concept.

Therewith, Pompeu et al. (2012) presented different scenarios that should be evaluated to define fish passage objectives, based on spatial distribution of critical habitats. These scenarios should be identified prior to the construction of a passage, favoring decision-making related to the need of such facility (Lopes \& Silva, 2012). Thus, with clear objectives defined fish passage planning and monitoring programs would be more consistent. Unfortunately, most of the passages in Brazil were constructed based on mandatory decisions with no clear objectives, resulting in several facilities with postconstruction issues and poor monitoring programs that did not allow efficiency evaluation.

Post-construction issues could be related to the absence of satisfactory operational rules related to fish distribution below the dam and failure of the attraction system to allow fish to locate and enter the passage. For fish ladders ascension could also be another issue. Therefore, evaluation of temporal distribution of fish below the dam (Agostinho et al., 2007c; Bizzoto et al., 2009), attraction discharge to encourage fish to enter the fish ladder (Fernandez et al., 2007a) and the ascension and passage through the facility (Makrakis et al., 2007; Makrakis et al., 2011; Agostinho et al., 2007b) constitute basic information that could help the identification of postconstruction issues, improving fish ladder design and operation, optimizing efficiency to match its defined objectives, which have to be evaluated with broader monitoring programs. 
The fish ladder at Baguari Dam was constructed aiming the maintenance of viable populations of migratory fish, although allochthonous migratory species were present in that river stretch. However, managers had considered artificial stocking as a secondary objective to maintain fisheries activities due to a lawsuit enforced by fishermen. Furthermore, apparently the lack of specific studies before the fish ladder construction led to functionality issues and possible ecological problems that have to be discussed.

This study evaluated the functionality of the Baguari Dam fish ladder identifying post-construction issues related to operational rule and location of the fish ladder entrance. It also discussed possible ecological problems due to the passage of allochthonous migratoy species. To accomplish that the following questions were addressed: i) Do the fish species (migratory, migratory allochthonous and non-migratory) concentrate below the dam in a temporal pattern fashion allowing the definition of an operational rule? ii) Are migratory allochthonous species using and passing through the ladder? iii) Is the attraction to the fish ladder entrance influenced by the dam operation (turbine and spillway discharge)? iv) Are fish ascending the ladder?

\section{Material and Methods}

\section{Study area}

The Doce River basin is inserted in a group of independent watersheds draining the Brazilian Southeastern region to the Atlantic Ocean (ANA, 2001). According to its environmental characteristics the river is divided in upper, middle, and lower stretches. The middle Doce River has typical lacustrine environments and more turbid water (Vieira, 2009).

Baguari Dam is located in the middle stretch close to the municipality of Governador Valadares, Minas Gerais State (Fig. 1), between Aimorés Dam (168 km downstream) and Risoleta Neves (Candonga) Dam (170 km upstream) and both dams have a fish passage facility (fish ladder and trap and truck system, respectively). Filling the reservoir was completed in 2009 starting its operation in August. The dam is a run-ofthe-river power plant $295 \mathrm{~m}$ in length, $18 \mathrm{~m}$ in height and a flooded area of $16 \mathrm{~km}^{2}$. The residence time of the reservoir is about 3.1 days and the annual average flow is $568 \mathrm{~m}^{3} / \mathrm{s}$. There is $150 \mathrm{~km}$ of lotic environment upstream the reservoir and two major tributaries (Corrente Grande and Santo Antônio rivers). Also, spawning and rearing habitats are likely available both down and upstream of Baguari Dam.

The fish ladder constructed at Baguari Dam is of the vertical-slot type, approximately $230 \mathrm{~m}$ long, with $8 \%$ slope and 91 pools divided in three straight sections connected by two turnpools tanks. The dimension of each pool is $3 \times 2.6 \times 3$ $\mathrm{m}$ with a vertical slot width of $0.3 \mathrm{~m}$ connecting the pools. The turnpools are $6 \mathrm{~m}$ wide and provide a resting area for the fish. The fish ladder flow is regulated by a sluice gate located upstream (reservoir) and downstream (tailrace) and during the entire study period it was maintained at about $6 \mathrm{~m}^{3} \cdot \mathrm{s}^{-1}$. Hydrological data for the fish ladder was supplied by the Baguari Dam Consortium. The total fish ladder height is 17.5

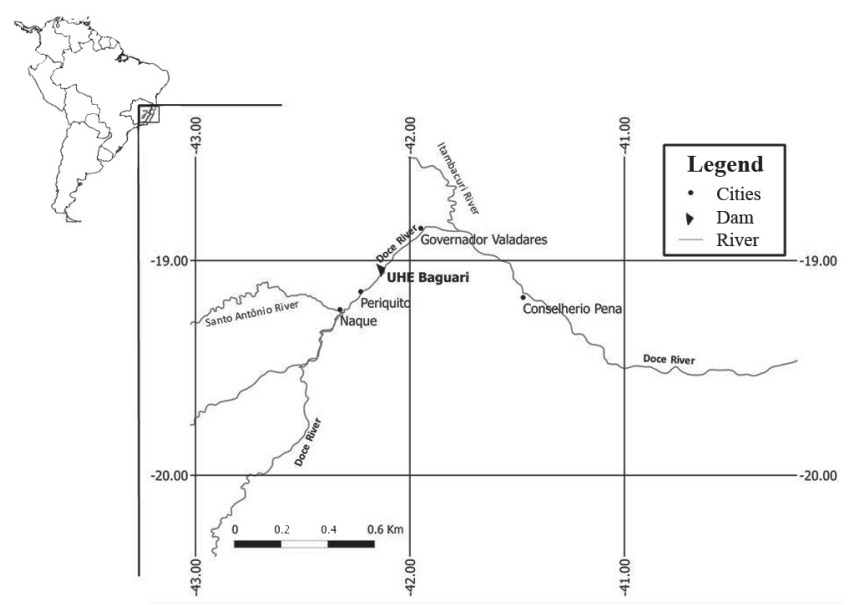

Fig. 1. Location of Baguari Dam in the middle Doce River Basin, Minas Gerais State, Brazil.

$\mathrm{m}$ and drop per pool around $0.2 \mathrm{~m}$. Nominal flow range and attraction flow data for the study period was not available.

The attraction channel was built underneath the final stretch of the fish ladder (from upstream to downstream) following the same $8 \%$ slope. At the end of this stretch the channel is suddenly interrupted and the water drops $8 \mathrm{~m}$ to the entrance of the fish ladder located at the right side of the tailrace. To regulate the flow a sluice gate was installed at the beginning of the attraction channel that is operated according to the reservoir and tailrace water level variation. However, for this study the attraction flow was not regulated because the operational rule for the fish ladder has not been developed yet.

Baguari Dam has a S-shape with the spillway gates located towards the right shore and the tailrace in the left shore of the Doce River. The spillway was constructed at the former river bed and the spill bay is approximately $160 \mathrm{~m}$ wide, characterized by a rocky-sandy substrate (Fig. 2). During spillage events (flood season) this area is flooded creating rapids and a residual flow of $15 \mathrm{~m}^{3} \cdot \mathrm{s}^{-1}$ is maintained in the drought season to provide habitat for fish in pools between the rocks. The tailrace is deeper than the spill bay and is approximately $110 \mathrm{~m}$ wide, characterized by a sandy substrate.

\section{Sampling sites and data analysis}

Fish sampling was conducted monthly just below the dam and inside the fish ladder from January 2010 to July 2011. However, samples were not taken in August and September 2010 due to an interruption in the fish ladder operation to allow the dam managers to conduct structure adjustments in the pools deflectors and in the attraction channel sluice gate. Also, during the reproductive season (October to March) (Pompeu \& Martinez, 2007) sample effort was increased with two sampling trips per month. Thus, a total of 14 samples were carried out in the reproductive season (RS) and 6 in the non-reproductive season (NRS). Vouchers are catalogued in the Ichthyological Collection of the Taxonomic Collections of the Universidade Federal de Minas Gerais and were labeled as MHN-UFMG 1570 to MHN-UFMG 1587. 


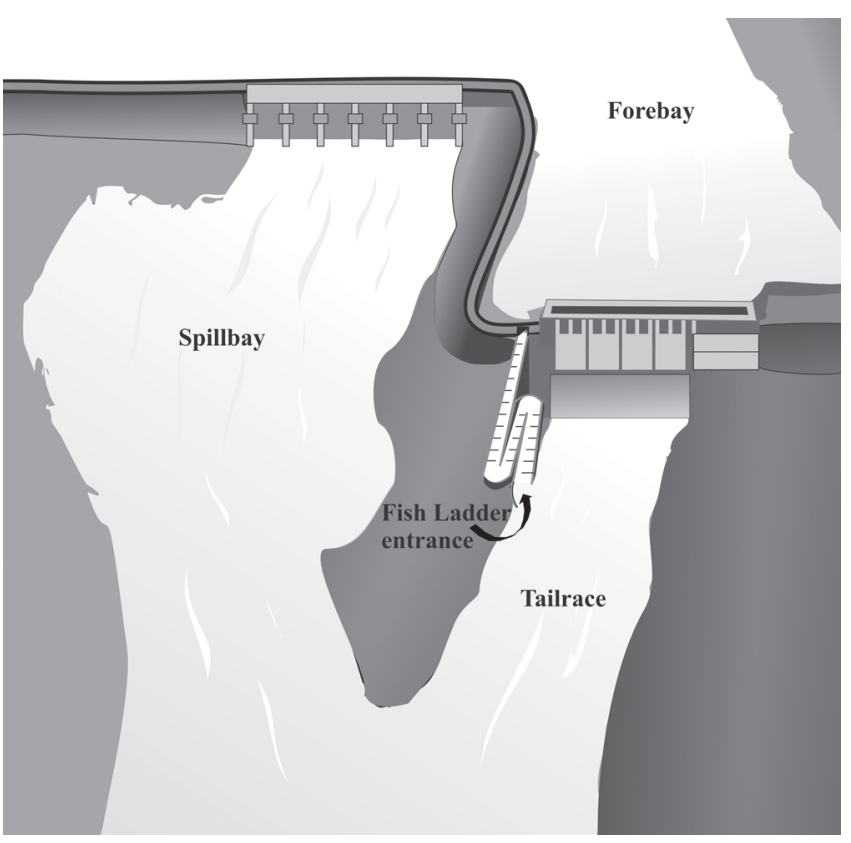

Fig. 2. Schematic view of the Baguari Dam with the positioning of the fish ladder entrance.

Below the dam fish were sampled immediately downstream in the tailrace and spill bay. Samples were taken using gill nets of different mesh sizes ( 3 to $16 \mathrm{~cm}$ between opposite knots, $10 \mathrm{~m}$ long and $1.5 \mathrm{~m}$ high) deployed at dusk and checked at dawn with an exposure period of approximately $14 \mathrm{~h}$. In the fish ladder visual inspections were conducted throughout the fish ladder to identify the species and count the number of individuals for abundance estimates. This survey was conducted after reducing the flow and consequently the water level to a minimum necessary to keep fish alive. When necessary individuals were sampled using hand nets to confirm identification or to facilitate counting. Drop back of fish was avoided by using a screen released in the slot of the fish ladder. For each sample obtained from November 2010 to June 2011, the fish ladder was divided into three stretches (lower, middle and upper in downstream to upstream order) and the total number of individuals was recorded for each species on each stretch. Except for the first 10 pools after the fish ladder entrance (due to the impossibility of dewatering that area), each stretch comprised 27 pools that were inspected.

Captured fish were grouped according to their reproductive strategy into migratory (M), migratory allochthonous (MA) and non-migratory (NM) species, based in the literature (Pompeu \& Martinez, 2007; Vieira, 2009; Sato \& Godinho, 2003, Bizzotto et al., 2009). Allochthonous and exotic species were defined according to Alves et al. (2007b). Fish abundance for each group was indexed by the capture per unit effort (CPUEn) expressed by the number of individuals captured per $100 \mathrm{~m}^{2}$ gillnet.14 hours ${ }^{-1}$ (Hubert \& Fabrizio, 2007) for each sample taken downstream and by the total number of individuals counted inside the fish ladder. Occurrence was considered as the number of samples in which each species was registered below the dam and in the fish ladder. Also, Shannon diversity and Equitability indexes (Begon et al., 2006) were calculated to verify species dominance on each sample site.

The temporal distribution of fish downstream and inside the fish ladder was explored graphically, using the relative abundance (\% CPUEn and \% of individuals inside the fish ladder) and species richness. The relationship of fish abundance with dam discharge was evaluated using linear regression for downstream and for the fish ladder separately, considering the different methods used to sample for fish at these sites. The variation in abundance and richness was interpreted over the sample periods downstream but only from November 2010 to June 2011 for the fish ladder. The Kruskal-Wallis test was conducted to compare the variation of CPUEn and total abundance in the ladder of fish groups (M, MA, NM) among periods (RS, NRS). Species richness was compared using a rarefaction curve (species x samples) calculated with Estimate S (Colwell, 2012).

The attraction of the fish ladder was evaluated using the occurrence of fish species below the dam and in the fish ladder for each sample. Presence/absence of fish species for each sample site was coded 1 or 0 , respectively. Comparisons were made using the Cochran Q test, considering that in an optimal condition the presence of fish in the fish ladder would be related to its occurrence downstream. Also, the CPUEn was calculated for the tailrace and spill bay separately and compared using the Wilcoxon test to evaluate whether fish were concentrated close to the fish ladder entrance (tailrace) or away from it (spill bay).

To analyze the ascent of fish through the ladder, the KruskalWallis test was conducted to compare the abundance for each fish group (M, MA, NM) among ladder stretches (lower, middle and upper), considering that in an ideal situation of free transit fish abundance would be similar over the length of the ladder (Agostinho et al., 2007c) and the entrance of fish from the reservoir would be very low (Agostinho et al., 2007b).

The attraction of the fish ladder and the ascent of fishes were also evaluated for three species of M and MA groups that were the most abundant during the study (Leporinus conirostris, Pimelodus maculatus, and Prochilodus costatus). Normality of the data was verified using Shapiro-Wilk's test. Given the nonnormal distribution of the data, nonparametrics tests were chosen. All statistical analyses were conducted using the software Statistica 10, described by Sokal \& Rohlf (1995) and StatSoft (2011). Significant results were considered at a 95\% level.

\section{Results}

\section{Composition and temporal distribution of fish fauna}

A total of 8,066 individuals were registered in the study of which 7,062 were collected inside the fish ladder and 1,004 below the Baguari Dam, respectively. The fish fauna was composed of 40 species of which $29(72.5 \%)$ were recorded in the fish ladder, 31(77.5\%) in the river downstream and $20(50 \%)$ were common to both sample sites. Furthermore, from the 
total species in the study $9(22.5 \%)$ were registered exclusively in the fish ladder (Table 1). Among fish groups in the ladder, richness of non-migratory species was greater than migratory species with 23 (79.3\%) and $6(20.7 \%)$ species, respectively. Diversity values were similar for both sites and both seasons (RS and NRS) except for the fish ladder in the NRS (Shannon $=1.10$; Equitability $=0.37)$ (Table 1$)$. Also, during the RS 4 species dominated the fish ladder ( 2 migratory and 2 nonmigratory), composing $61 \%$ of the abundance registered. For the NRS 3 species from the NM group were dominant in the fish ladder, corresponding to $90.43 \%$ of the total abundance.

Considering groups, among migratory fish only three species were considered native from the Doce River basin and five were allochthonous species. The piau-branco Leporinus conirostris was the most abundant native migratory (M) mainly during the RS. The mandi-amarelo Pimelodus maculatus and the curimba Prochilodus costatus were the most abundant MA species in the fish ladder also in

Table 1. Relative abundance (CPUEn) downstream and relative frequency ( $\%$ of individuals inside the fish ladder) of nonmigratory, migratory and migratory allochthonous species captured in samples during the reproductive and non-reproductive period. $\mathrm{OC}=$ occurrence, number of samples in which the species was registered; $\mathrm{Fr}=$ relative frequency; $\boldsymbol{\Delta}$ Allochthonous species; $\square$ Exotic species (Alves et al., 2007b).

\begin{tabular}{|c|c|c|c|c|c|c|c|c|}
\hline \multirow{3}{*}{ Species } & \multicolumn{4}{|c|}{ Reproductive period (14 Samples) } & \multicolumn{4}{|c|}{ Non-reproductive period (6 Samples) } \\
\hline & \multicolumn{2}{|c|}{ Downstream } & \multicolumn{2}{|c|}{ Fish Ladder } & \multicolumn{2}{|c|}{ Downstream } & \multicolumn{2}{|c|}{ Fish Ladder } \\
\hline & CPUEn (\%) & $\mathrm{OC}$ & Abundance (\%) & $\mathrm{OC}$ & CPUEn $(\%)$ & $\mathrm{OC}$ & Abundance (\%) & $\mathrm{OC}$ \\
\hline \multicolumn{9}{|l|}{ Non-migratory } \\
\hline Astyanax aff. bimaculatus & 8.85 & 10 & 1.47 & 7 & 11.73 & 4 & 0.84 & 4 \\
\hline Astyanax fasciatus & 2.95 & 7 & 1.57 & 6 & 5.03 & 3 & 0.05 & 1 \\
\hline Cichla cf. kelberi $\mathbf{\Delta}$ & 0.86 & 3 & 2.98 & 4 & 1.12 & 2 & 2.76 & 2 \\
\hline Characidium cf. timbuiense & 0.00 & 0 & 0.22 & 6 & 0.00 & 0 & 0.05 & 1 \\
\hline Clarias gariepinus $\square$ & 1.97 & 6 & 1.14 & 5 & 0.00 & 0 & 0.00 & 0 \\
\hline Delturus carinotus & 10.44 & 11 & 2.63 & 11 & 4.47 & 4 & 0.44 & 4 \\
\hline Geophagus brasiliensis & 0.12 & 1 & 0.00 & 0 & 0.56 & 1 & 0.00 & 0 \\
\hline Glanidium melanopterum & 0.74 & 2 & 0.09 & 3 & 0.00 & 0 & 0.00 & 0 \\
\hline Gymnotus sp. & 0.49 & 2 & 0.02 & 1 & 0.00 & 0 & 0.05 & 1 \\
\hline Harttia sp. & 0.00 & 0 & 0.04 & 2 & 0.00 & 0 & 0.39 & 3 \\
\hline Hoplias intermedius & 2.33 & 10 & 0.02 & 1 & 1.12 & 2 & 0.05 & 1 \\
\hline Hoplias malabaricus & 2.21 & 9 & 0.00 & 0 & 1.12 & 2 & 0.00 & 0 \\
\hline Hoplosternum littorale $\mathbf{\Delta}$ & 0.25 & 2 & 0.00 & 0 & 0.00 & 0 & 0.00 & 0 \\
\hline Hypostominae new genus and sp. & 0.25 & 2 & 21.51 & 10 & 0.56 & 1 & 71.99 & 3 \\
\hline Hypostomus affinis & 6.27 & 13 & 4.83 & 11 & 12.85 & 6 & 8.53 & 5 \\
\hline Hypostomus auroguttatus & 16.58 & 14 & 4.08 & 9 & 28.49 & 6 & 1.04 & 3 \\
\hline Lophiosilurus alexandri $\boldsymbol{\Delta}$ & 0.98 & 6 & 0.00 & 0 & 0.00 & 0 & 0.00 & 0 \\
\hline Loricariichthys castaneus & 0.49 & 3 & 0.00 & 0 & 0.56 & 1 & 0.00 & 0 \\
\hline Oligosarcus argenteus & 10.69 & 10 & 3.56 & 7 & 17.32 & 4 & 1.28 & 5 \\
\hline Pachyurus adspersus $\mathbf{\Delta}$ & 0.00 & 0 & 0.00 & 0 & 1.12 & 1 & 0.00 & 0 \\
\hline Pimelodella sp. & 0.00 & 0 & 0.73 & 4 & 0.00 & 0 & 0.10 & 2 \\
\hline Pogonopoma wertheimeri & 0.12 & 1 & 0.21 & 3 & 0.00 & 0 & 0.00 & 0 \\
\hline Pseudauchenipterus affinis & 0.49 & 3 & 0.04 & 1 & 0.56 & 1 & 0.00 & 0 \\
\hline Pygocentrus nattereri $\boldsymbol{\Delta}$ & 1.84 & 5 & 0.00 & 0 & 0.56 & 1 & 0.00 & 0 \\
\hline Rhamdia quelen & 0.12 & 1 & 0.00 & 0 & 0.00 & 0 & 0.00 & 0 \\
\hline Serrapinnus heterodon & 0.00 & 0 & 4.77 & 8 & 0.00 & 0 & 0.74 & 3 \\
\hline Synbranchus marmoratus & 0.00 & 0 & 0.02 & 1 & 0.00 & 0 & 0.00 & 0 \\
\hline Tilapia rendalli $\square$ & 0.49 & 3 & 0.02 & 1 & 0.00 & 0 & 0.00 & 0 \\
\hline Trachelyopterus striatulus & 13.76 & 12 & 0.00 & 0 & 0.56 & 1 & 0.00 & 0 \\
\hline Trichomycterus cf. immaculatus & 0.00 & 0 & 0.26 & 2 & 0.00 & 0 & 0.00 & 0 \\
\hline Trichomycterus sp. 1 & 0.00 & 0 & 9.21 & 8 & 0.00 & 0 & 9.91 & 5 \\
\hline Trichomycterus sp. 2 & 0.00 & 0 & 0.28 & 1 & 0.00 & 0 & 0.00 & 0 \\
\hline \multicolumn{9}{|l|}{ Migratory } \\
\hline Brycon sp. & 0.00 & 0 & 0.00 & 0 & 0.56 & 1 & 0.00 & 0 \\
\hline Leporinus conirostris & 2.33 & 7 & 1.96 & 9 & 2.23 & 2 & 0.05 & 1 \\
\hline Prochilodus vimboides & 0.61 & 4 & 0.50 & 2 & 0.00 & 0 & 0.00 & 0 \\
\hline \multicolumn{9}{|l|}{ Migratory exotic } \\
\hline Leporinus elongatus $\boldsymbol{\Delta}$ & 0.00 & 0 & 0.28 & 4 & 0.00 & 0 & 0.00 & 0 \\
\hline Piaractus mesopotamicus $\mathbf{\Delta}$ & 0.12 & 1 & 0.00 & 0 & 0.00 & 0 & 0.00 & 0 \\
\hline Pimelodus maculatus $\mathbf{\Delta}$ & 8.11 & 13 & 18.86 & 11 & 4.47 & 4 & 1.58 & 3 \\
\hline Prochilodus costatus $\mathbf{\Delta}$ & 4.30 & 13 & 17.50 & 6 & 5.03 & 3 & 0.10 & 2 \\
\hline Salminus brasiliensis $\mathbf{\Delta}$ & 1.23 & 6 & 1.21 & 5 & 0.00 & 0 & 0.05 & 1 \\
\hline Total & 100.00 & & 100.00 & & 100.00 & & 100.00 & \\
\hline Richness & 29 & & 29 & & 20 & & 19 & \\
\hline Diversity (Shannon Index) & 2.66 & & 2.37 & & 2.24 & & 1.10 & \\
\hline Equitability & 0.79 & & 0.70 & & 0.74 & & 0.37 & \\
\hline
\end{tabular}


the RS. Among NM species the new genus and species of the subfamily Hypostominae was the most abundant both in the RS and NRS followed by Trichomycterus sp.1 and Hypostomus affinis (Table 1). Also, in the fish ladder the abundance of $\mathrm{M}$ and MA fish was greater during the $\mathrm{RS}(\mathrm{H}=4.14, \mathrm{p}=0.04 ; \mathrm{H}$ $=3.53, \mathrm{p}=0.05$, respectively). However, NM species were more abundant in the fish ladder for both RS and NRS $(\mathrm{H}=$ $11.8, p=0.002 ; H=12, p=0.002)$ (Fig. 3a).
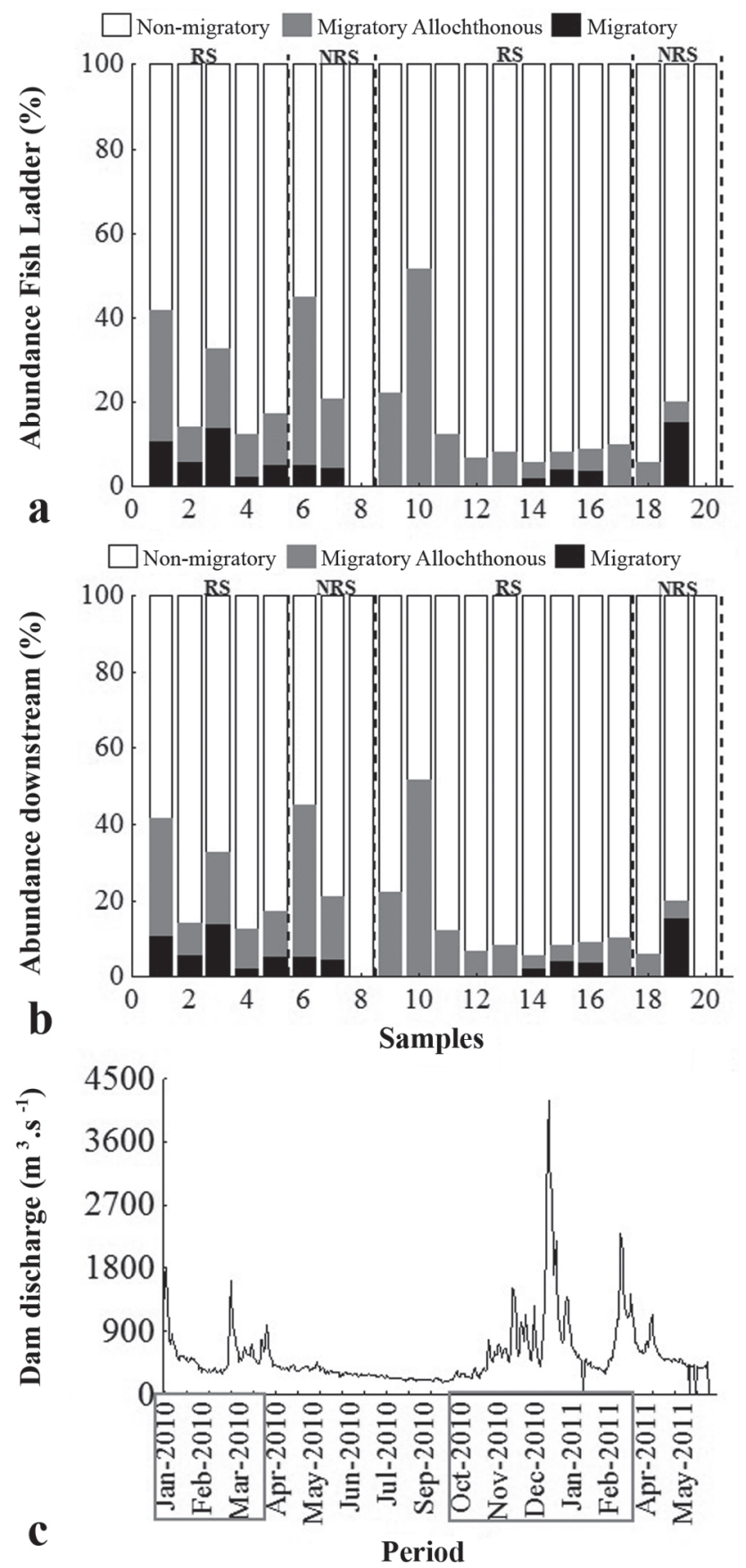

Fig. 3. Temporal variation of fish groups abundance inside the fish ladder (a) and downstream (b; CPUEn) of Baguari Dam, and total dam discharge (c) during the reproductive (RS / gray rectangle) and non-reproductive (NRS) season.
Below the dam the same trend was observed for $\mathrm{M}$ and MA species and $L$. conirostris, $P$. maculatus and $P$. costatus were the most abundant with a tendency of fish to concentrate downstream during the RS. Among NM the Siluriformes Hypostomus auroguttatus, Trachelyopterus striatulus, Delturus carinotus, and the Characiformes Oligosarcus argenteus were the most abundant species in the RS. Also, $H$. auroguttatus and $O$. argenteus were abundant in the NRS (Table 1). Moreover, NM species were the most abundant among groups for both $\mathrm{RS}$ and NRS $(\mathrm{H}=32.5, \mathrm{p}<0.001 ; \mathrm{H}=$ 12.7, $\mathrm{p}=0.002$ ) (Fig. 3b).

Indeed, the observed variation in the abundance of fish inside the fish ladder was related to the discharge below the dam (Fig. 3c). Regression analysis showed significant positive relation between these variables $\left(\mathrm{p}<0.014, \mathrm{r}^{2}=0.098\right)$. During the RS increment in discharge appears to attract more fish than in the NRS, increasing the abundance and richness. Except for the NM species, richness increased more rapidly in the RS and for MA species it was greater in the fish ladder (Fig. 4).

\section{Fish ladder attraction}

In regard to the fish ladder attraction no significant differences were registered for the fish groups. Generally, the presence of M, MA, and NM species downstream potentially indicates these species groups were present in the fish ladder. It suggests that somehow these species are being attracted to fish ladder to some extent. However, among the species of the MA group, significant difference was recorded for Prochilodus costatus (Cochran, $\mathrm{p}=0,008$ ) indicating that this species is likely occurring more frequently downstream than in the fish ladder. Also, although only one individual was captured, Piaractus mesopotamicus was recorded just downstream.

Considering that the spatial distribution of fish downstream a dam could influence the ability of fish to locate the fish ladder entrance, the analysis of abundance separately for the tailrace and spill bay indicated significant differences for the MA and NM groups during the RS (Wilcoxon, $p=$ 0.009 and $p=0.006$ for the MA and NM respectively). Basically, more fish of these groups were recorded in the spill bay compared to the tailrace. Also, for MA species, significant differences were registered for Prochilodus costatus abundance in the spill bay compared to the tailrace (Wilcoxon, $p=0.004)$ in the RS. Apparently, the increase in abundance of fish in the spill bay is coincident with the increase in flow at the spill bay during spillage events (Fig. 5).

\section{Ascent of fishes through the ladder}

The abundance of migratory fish groups throughout different stretches of the ladder suggests that ascending the pools would not be an issue for most species, although the transit time along the fish ladder was not evaluated. No significant differences were found for fish abundance of $\mathrm{M}$ and MA groups among the lower, middle and upper stretches. For the NM group a significant difference was observed $(\mathrm{H}=$ $6.32 ; \mathrm{p}=0.04)$ indicating that more fish were registered in the lower stretch compared to the others (Fig. 6a). 
Furthermore, looking at the most abundant species among the M and MA group (L. conirostris, Prochilodus costatus and Pimelodus maculatus) they also had an even distribution along the stretches (Fig. 6b).

\section{Discussion}

It is known that most of the times the decision to construct a fish passage is made either based on public and government agency pressure, or the decision is mandatory, which ignores the lack of proper supporting studies and data (Agostinho et al., 2002; Pompeu et al., 2012). Yet, it is expected that fish passages would play an important role as a fisheries conservation tool which is their principal objective. However, a secondary objective of keeping fisheries stocks in the reservoir had been considered for fish passages in Brazil (Godinho \& Kynard, 2008) and only broader studies to evaluate the efficiency of these facilities would be able to determine which objective is being achieved (Pompeu et al., 2012). Nevertheless, basic data regarding selectivity (Agostinho et al., 2002; Fernandez et al., 2007b), ascent (Agostinho et al., 2007b; Agostinho et al., 2007c; Makrakis et al., 2011) and influence of abiotic factors in fish movements
(Fernandez et al., 2007a; Bizzotto et al., 2009) gathered from studies focused in the fish passage itself is still very important due to their possible use for designing new structures. Pompeu et al. (2012) have already stated that improvements were achieved to pass fish upstream based on data gathered with basic monitoring and with the development of new research projects to approach specific variables such swimming capability.

Considering this context, the data obtained for the fish ladder at Baguari Dam allowed the discussion and formulation of questions showing different problems that could emerge when the decision is somehow mandatory and the studies are not planned to support it. These problems could be either structural (e.g. absence of operational rules, fish ladder location) or ecological (e.g. population dynamics, dispersion of allochthonous species, recruitment) requiring studies focused in different aspects of the passage. Structural problems could be evaluated with monitoring programs focused on the fish passage functionality. However, ecological problems will only be assessed with broader studies which had been discussed and alerted in the literature (Pelicice \& Agostinho, 2007; Pompeu et al., 2012). Unfortunately, the monitoring program of the Baguari Dam fish ladder was
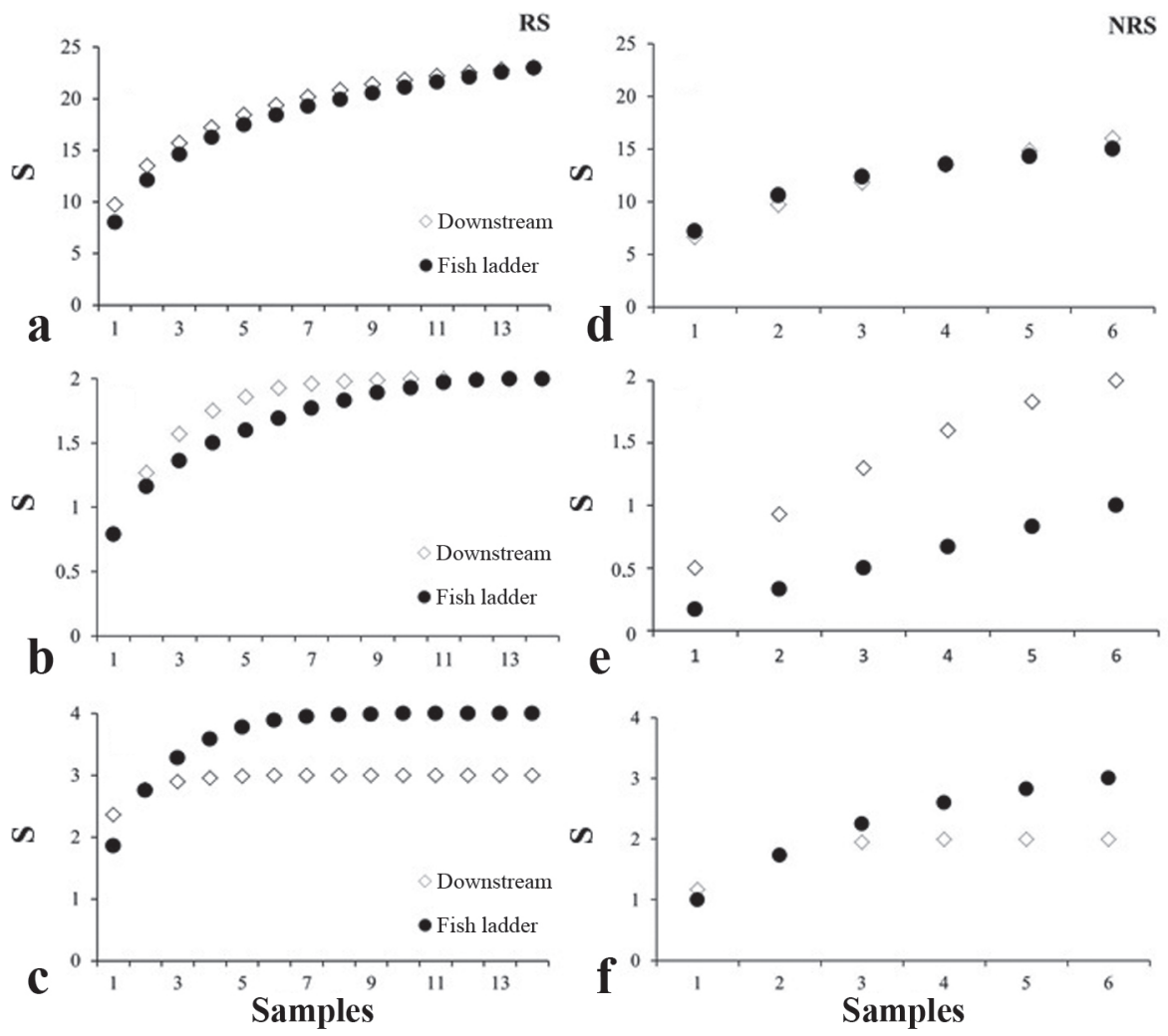

Fig. 4. Temporal variation of fish groups (a and $\mathbf{d}$ - non-migratory; $\mathbf{b}$ and $\mathbf{e}$ - migratory; $\mathbf{c}$ and $\mathbf{f}$,- migratory allochthonous) richness (S) downstream and inside the fish ladder of Baguari Dam along the reproductive (RS - left column) and nonreproductive (NRS - right column) season. 
restricted to its functionality and did not allow ecological evaluations but provided insights related to possible issues that might interfere with the conservation objective.

An appropriate first structural question is related to temporal distribution: i) Is it possible to establish an operational rule for the Baguari fish ladder based on temporal distribution data? Temporal distribution of fish downstream and inside the fish ladder of the Baguari Dam showed that the migratory species mostly concentrate in the area during the
RS (October to March), although only two allochthonous species dominated. However, the occurrence and abundance of the native $L$. conirostris were also greater for this period. Makrakis et al. (2007), Fernandez et al. (2007a), Agostinho et al. (2007c), and Bizzotto et al. (2009) also recorded a marked seasonality on movements of migratory fish for different river basins (Paraná, Tocantins, and Grande basins) showing that the majority of species were registered in periods also varying from October to March. On the other hand, for the NRS non-
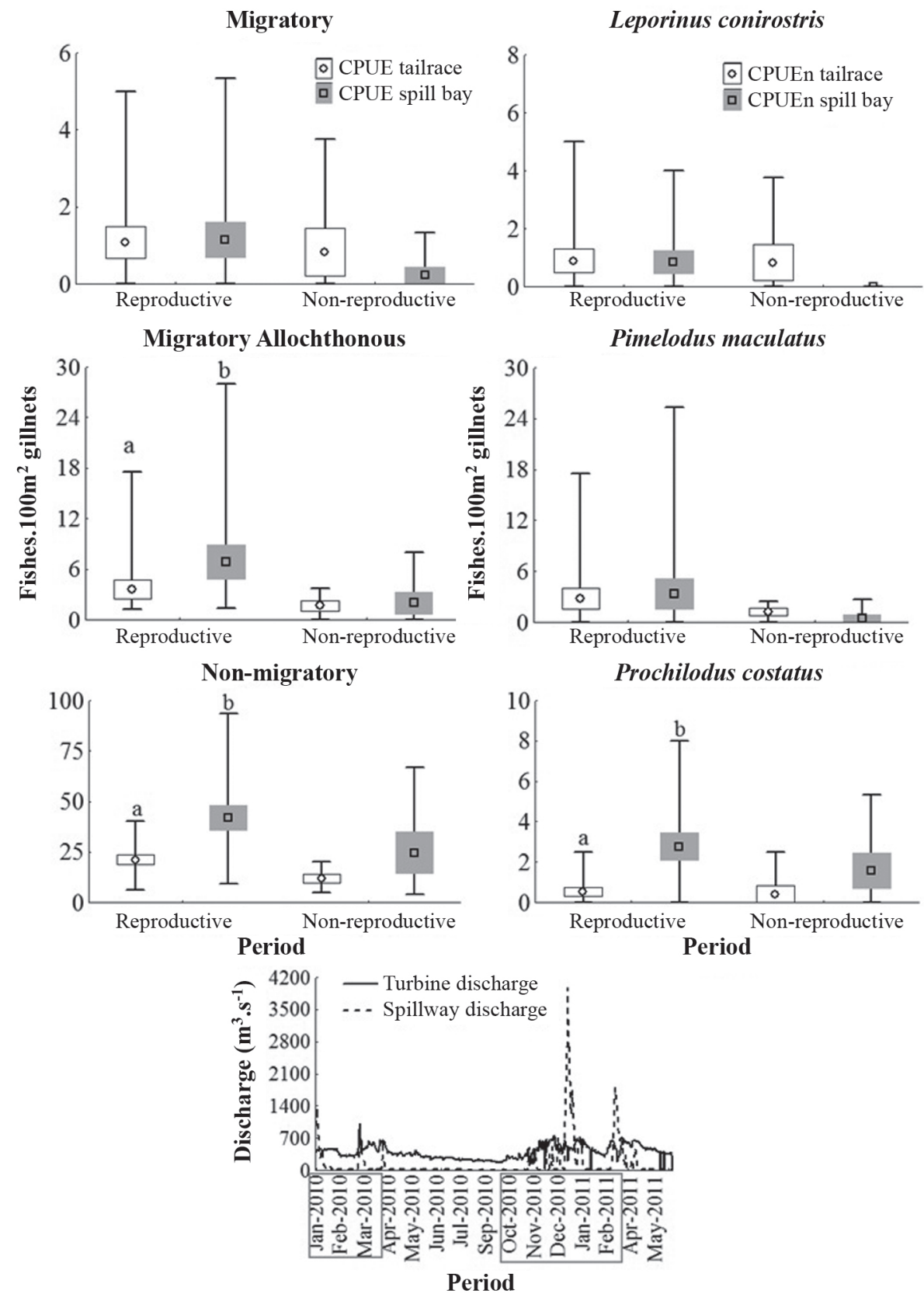

Fig. 5. Abundance variation of fish groups (right column) and species (left column) in the tailrace and spill bay area of the Baguari Dam for the reproductive and non-reproductive season compared to the turbine and spillway discharge (bottom). Gray rectangle indicates the reproductive season. 
migratory species dominated occurrence and abundance both downstream and in the fish ladder. Higher abundance of NM species was also registered by Bizzotto et al. (2009) during the dry season. Also, high dominance of NM species in the Baguari fish ladder during the NRS was due to the abundance of armored catfishes which appeared to be resident in the fish ladder due to their occurrence throughout the samples. Agostinho et al. (2007c) also observed the presence of resident species inside the fish ladder at Lajeado Dam, although they were migratory. Species dominance appeared to be a regular pattern among fish passages in Brazil (Pompeu et al., 2012).

Thus, probably the Baguari fish ladder should be operated during the RS only, given the greater abundance of migratory fish in this period, considering that it has to achieve its principal objective (i.e. maintain viable populations). However, during the NRS resident species were abundant requiring caution in
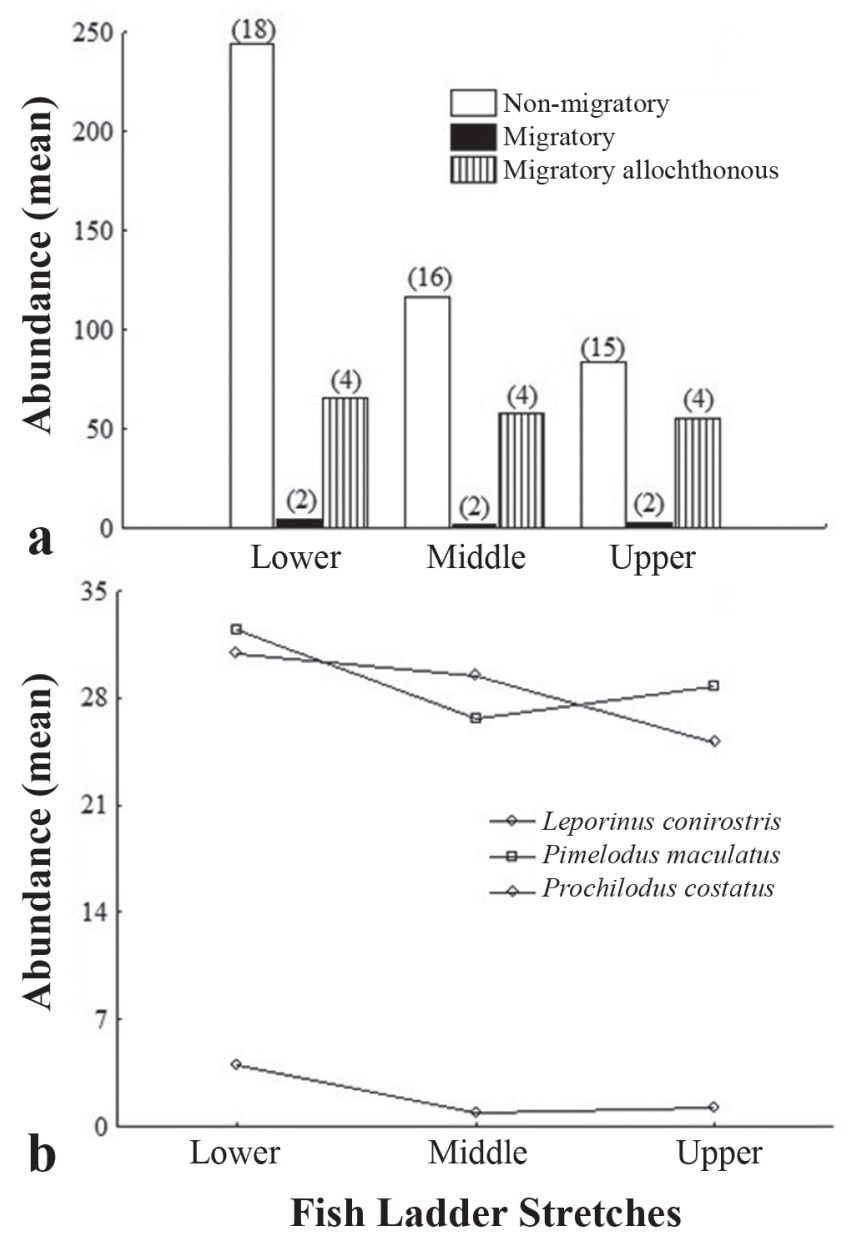

Fig. 6. Abundance of fish groups (a) and species (b) along different stretches of the Baguari Dam fish ladder. Each stretch included 27 pools. Lower $=$ first stretch after the fish ladder entrance. Upper $=$ last stretch connected to the reservoir. Number in parenthesis indicates richness for each group. taking this decision because it will be necessary to remove all the fish from inside the fish ladder. Certainly, for a more accurate decision, broader studies must be carried out, especially to identify critical habitats, such as spawning and rearing areas down and upstream verifying whether the ladder could be achieving its principal objective. Also, the effects of the ascent of fish through Aimorés Dam fish ladder located downstream should be taken in consideration to evaluate its influence on the transit of fish at Baguari. Establishing an operational rule and managing the Baguari fish ladder based on passage at Aimorés Dam could increase its functionality and minimize further impacts on fisheries stocks over time. Unfortunately, few studies in South America have attempted to approach this question and the majority of fish passages already built in Brazil do not have an operational rule regarding the proper period to operate and pass target species.

For example, Lopes et al. (2007) suggested a change in the operational rule of the fish ladder at Canoas I (Paranapanema River) by closing the passage during the RS to allow migratory species, such as Salminus brasiliensis, to migrate to a potential spawning site in a tributary downstream and opening the passage in the NRS to promote the maintenance of stocks in the reservoir. Pompeu \& Martinez (2005) suggested an operational rule for the trap and truck facility located at Santa Clara Dam (Mucuri River), indicating that November to March was the best period to operate the system, which could improve the number of individuals passed and reduce costs associated with water loss through the passage.

A second question is related to the passage of allochthonous species, referring to a possible ecological issue. Agostinho et al. (2002) have already referred to the passage of non-native species as a potential impact for native fish stocks in the reservoir and for the river basin upstream. Also, Makrakis et al. (2007) showed, for the fish ladder located at the Engenheiro Sérgio da Motta Dam, a problem with the presence of non-native predators influencing the movements of native species. Thus, are migratory fish using and passing through the Baguari Dam fish ladder? Among the 12 nonnative species recorded in this study seven were sampled in the fish ladder, of which four are considered migratory. According to Vieira (2009) among those seven species, Pygocentrus nattereri, Piaractus mesopotamicus, Pimelodus maculatus, and Leporinus elongatus have not been recorded in the upper Doce River basin. Considering that the upstream Risoleta Neves Dam is close to the transition between the middle and upper stretches, even if those species ascend the Baguari Dam fish ladder their 'introduction' in the upper part would rely on passing through Risoleta Neves, which is possible because of the trap and truck system operating there. However, the likelihood of passing allochthonous fish through Risoleta Neves Dam is lower considering that managers would be able to manage the species before transporting them to the release sites.

For the other migratory species Prochilodus costatus and Salminus brasiliensis their occurrence was already established in the entire Doce River and they are appreciated by the local 
fisherman (Vieira, 2009). However, besides the local fishery appreciation, it is necessary to evaluate possible impacts of these species over the native ones, conducting studies to analyze the influence, such as competition and predation. In this case, the fish passage at Baguari Dam does not appears to play an important role in the conservation of the native migratory fish fauna but could be acting as a source-sink system (Godinho \& Kynard, 2008), which requires a rigorous and broad monitoring program to evaluate its effects (Pompeu et al., 2012). Thus, the passage would be accomplishing a secondary objective (i.e. artificial stocking) reinforcing that the fish ladder could be operated only at the RS.

The third question applies to the fish ladder entrance and attraction flow. Are fish able to locate the entrance and is the attraction flow sufficient to drive fish to the ladder? Data gathered in this study showed that most fish were able to locate the ladder entrance although higher abundance of migratory and non-migratory species was recorded for the spill bay during the RS. Because Baguari Dam is a run-of-theriver facility, spillage events often occur during this period and this result suggests that perhaps the spillway discharge is driving more fish to the spill bay than the attraction flow to the fish ladder entrance. It is known that the attraction flow should be sufficient to allow fish to locate the entrance of the passage quickly but with water velocities low enough to let them progress upstream against the current (Fernandez et al., 2007a). Also, the water velocity within the ladder entrance should be higher than in the river downstream. At Baguari Dam the higher the spillway discharge the more fish are attracted to the spill bay area where the former river bed was located. Therefore, due to the turbulence generated in the area many individuals were captured with external injuries even inside the fish ladder, indicating that probably those individuals moved between the spill bay and the tailrace.

Many other studies have discussed the efficiency of the attraction flow to guide fish to the entrance of the passage. In addition to the fish ladder at Baguari Dam, Makrakis et al. (2007) suggested that the ladder at the Engenheiro Sérgio da Motta Dam may have problems attracting fish. Also, Silva (2004) observed that Prochilodus lineatus moving upstream at the Grande River remained for one year at the tailrace of Igarapava Dam prior to entering the fish ladder. For the fish lift at Yacyretá Dam, Oldani et al. (2007) discussed that the flow probably is not sufficient to attract large migratory fish. On the other hand, the proximity of the experimental fish ladder at Itaipu Dam to the turbines appeared to explain the positive relationship between fish abundance in the facility and turbine discharge (Fernandez et al., 2007a). Nevertheless, this result should be evaluated more closely.

The attraction flow for the fish ladder at Baguari Dam has to be manipulated according to the water levels up and downstream, by operating the sluice gate. The sluice gate aperture is determined by water level variation and this was not established during the study period. Thus, the correct hydraulic conditions to attract more fish to the ladder entrance were achieved randomly and, perhaps, greater abundance would be observed in the facility if it were operated accordingly. Also, to determine more precisely whether fish move towards the spill bay or the tailrace during different dam operation, studies using technologies such as radiotelemetry should be conducted.

Another question arises from the data analysis and is related to the fish ladder entrance location. Is it located in the correct spot? It appears that for the Baguari Dam a fish ladder positioned in the spill bay would be more effective than in the tailrace or, despite the costs, perhaps in both places it would be better. Therefore, an important criticism relies on the fact that, unfortunately, siting of fishway entrances tend to be determined after a project is defined and are not based on preconstruction survey of fish abundance and distribution. Few scientific data are available for fish passages in Brazil regarding hydraulics and engineering features favorable for fish passage (see review in Roscoe \& Hinch, 2010). For example, considering all the fish passages located at Minas Gerais State, it has been known that only for the Retiro Baixo Dam (trap and truck system) was the location of the facility defined based on results gathered from tests in a model (E. M. F Viana \& C. B. Martinez, unpublished data). For other regions, experimental passages were installed at Itaipu Dam (Fernandez et al., 2004), at the Engenheiro Sérgio da Motta Dam (Makrakis et al., 2007) and, recently, at the Santo Antônio Dam in the Madeira River (A. L. Godinho \& R. A. C. Junho, unpublished data). Katopodis \& Williams (2011) described that, historically, empirical and 'trial and error' approaches to develop fish passages often failed and since the 1900s effort was increased in Europe to develop scientific laboratory and field test to evaluate different fishways designs. In Brazil, apparently due to the cost of constructing a model, this stage is frequently neglected and decisions are made exclusively based on empirical engineering data. However, it is important to note that after the construction of fish passages few studies were conducted to evaluate hydraulic parameters (see Viana et al., 2007 and Viana et al., 2010 for examples).

The last question is related to the ascension of fish through the ladder: are fish able to ascend the ladder? Significant higher abundance was observed only for the non-migratory group in the lower stretch of the fish ladder which means that the M and MA species were able to move upstream along the facility. Agostinho et al. (2007c), Makrakis et al. (2007), and Fernandez et al. (2007b) observed that significantly fewer fish were sampled in the upper parts of the fish ladder of the Lajeado Dam, Engenheiro Sérgio da Motta Dam and the experimental facility at Itaipu Dam, respectively. The ascension of fish depends of various factors, from diel period to correct hydraulics in the passage that allows fish to negotiate the passage through the pools in a shorter time period. Although the methodology used in the present study did not allow individual analysis of fish movement, it suggests that the migratory species might not have problems to negotiate the passage. Nevertheless, it is 
still necessary to estimate the transit time of fish through the ladder at the Baguari Dam. One key feature for a successful passage is the effectiveness of the facility to pass the migratory barrier (dam) with minimal delay (Williams et al., 2011). Whether the hydraulic parameters defined for the passages in Brazil are effective in allowing fish to pass upstream with no biological interference is unknown, and important in considering conservation purposes. The use of PIT tag system at Baguari Dam fish ladder combined with an evaluation of the reproductive condition of fish could be an efficient method to evaluate this issue.

Although most of the fish passages evaluations conducted in Brazil were restricted to analyze the attraction, selectivity and ascension issues, these data are still of paramount importance to approach management decisions (operational rules) at existing structures and improvements for the construction of new facilities. Williams et al. (2012) and Katopodis \& Williams (2011) showed that this kind of information was very important to develop more efficient fish passages in Europe and North America, but highlighted that real improvements were achieved after engineers and biologists had started working together toward those benefits. Although there are a few groups in Brazil trying to establish research programs considering both engineering and biological approaches, the efforts are still insufficient and mostly of the design of new passages are still restricted to engineer's knowledge, decisions and priorities. Agostinho et al. (2007a) has discussed that, for the energy companies and environmental agencies, the concept of an efficient fish passage relied on the perception and observation of environmental technicians of private companies and were not related to scientific information in most cases. Therefore, there is an urgent need to open a dialog across scientific, academic, and corporate boundaries to assist decision-making before and after fish passage construction. Lopes \& Silva (2012) bring an interesting approach that should be considered by the companies of the energy sector to manage decisionmaking regarding the construction and monitoring of new fish passages in Brazil.

In conclusion, the Baguari Dam fish ladder apparently has structural and ecological issues. Structural issues are related to the attraction of fish and location of the passage entrance, and ecological issues relied on the establishment of an operational rule, movements of migratory allochthonous species and the contribution of the facility to maintain viable populations of migratory fish upstream of the dam. However, ecological issues would only be assessed with the development of broader studies. Thus, to avoid these problems, the decision to construct fish passages should rely on science-based engineering and biological studies that better define design characteristics, engineering criteria, and operational parameters for fish passage structures that produce effective designs of known performance. Finally, technicians of the environmental agencies must be aware of this discussion and somehow it might have to be included as a basic requirement in the licensing program of new dams.

\section{Acknowledgments}

We would like to thank Gustavo Tavares Martins and Micheline C. Fialho Rodrigues on behalf of the Baguari Dam Consortium for the logistical support during the study and Rodrigo Alvarenga and Michelle Drummond Rocha on behalf of Biocev Meio Ambiente for the management of the monitoring program.

\section{Literature Cited}

Agência Nacional de Águas - ANA. 2001. Bacias Hidrográficas do Atlântico Sul - Trecho Leste: sinopse de informações do Rio de Janeiro, Espírito Santo, Bahia e Sergipe. Brasília (Série Sistema Nacional de Informações sobre Recursos Hídricos Documentos), 42p.

Agostinho, A. A., L. C. Gomes, D. R. Fernandez \& H. I. Suzuki. 2002. Efficiency of fish ladders for Neotropical ichthyofauna. River Research and Applications, 18: 299-306.

Agostinho, A. A., S. M. Thomaz \& L. C. Gomes. 2005. Conservation of the Biodiversity of Brazil's Inland Waters. Conservation Biology, 19: 646-652.

Agostinho, A. A., L. C. Gomes \& F. M. Pelicice. 2007a. Ecologia e manejo de recursos pesqueiros em reservatórios do Brasil. Maringá, EDUEM, 501p.

Agostinho, A. A., E. E. Marques, C. S. Agostinho, D. A. Almeida, R. J. Oliveira \& J. R. B. Melo. 2007b. Fish ladder of Lajeado Dam: migrations on one-way routes? Neotropical Ichthyology, 5: 121-130.

Agostinho, C. S., C. R. Pereira, R. J. Oliveira, I. S. Freitas \& E. E. Marques. 2007c. Movement through a fish ladder: temporal patterns and motivations to move upstream. Neotropical Ichthyology, 5: 161-167.

Alves, C. B. M., L. G. M. Silva \& A. L. Godinho. 2007a. Radiotelemetry of a female jaú, Zungaro jahu (Ihering, 1898) (Siluriformes: Pimelodidae), passed upstream of Funil Dam, rio Grande, Brazil. Neotropical Ichthyology, 5: 229-232.

Alves, C. B. M., Vieira, F., Magalhães, A. L. B. \& Brito, M. F. G. 2007b. Impacts of non-native fish species in Minas Gerais, Brazil: Present situation and prospects. Pp. 291-314. In: Bert, T. M. (Ed). Ecological and genetic implications of aquaculture activities. Florida, Springer, 548p.

ANEEL. 2008. Atlas da energia no Brasil. Agência de Energia, Brasília, 3 Ed, 236p.

Begon, M., Townsend, C. R. \& Harper, J. L. 2006. Ecology: From individuals to ecosystems. Oxford: Blackwell Publishing, 759p.

Bizzotto, P. M., A. L. Godinho, V. Vono, B. Kynard \& H. P. Godinho. 2009. Influence of seasonal, diel, lunar, and other environmental factors on upstream fish passage in the Igarapava Fish Ladder, Brazil. Ecology of Freshwater Fish, 18: 461-472.

Carolsfeld, J., B. Harvey, C. Ross \& A. Baer. 2003. Migratory fishes of South America: Biology, fisheries and conservation status. Ottawa: World Fisheries Trust, 371p.

Colwell, R. K. 2012. EstimateS 5: statistical estimation of species richness and shared species from samples. Version 8.2.0.

Drummond, G. M., C. S. Martins, A. B. M. Machado, F. A. Sebato \& Y. Antonini. 2005. Biodiversidade em Minas Gerais: um atlas para sua conservação. Belo Horizonte, Fundação Biodiversitas, $2^{\mathrm{a}} \mathrm{Ed}, 222 \mathrm{p}$.

Fernandez, D. R., A. A. Agostinho, L. M. Bini. 2004. Selection of an experimental fish ladder located at the dam of the Itaipu 
Binacional, Paraná River, Brazil. Brazilian Archives of Biology and Technology, 47: 579-586.

Fernandez, D. R., A. A. Agostinho, L. M. Bini \& L. C. Gomes 2007a. Environmental factors related to entry into and ascent of fish in the experimental ladder located close to Itaipu Dam. Neotropical Ichthyology, 5: 153-160.

Fernandez, D. R., A. A. Agostinho, L. M. Bini \& F. M. Pelicice. 2007b. Diel variation in the ascent of fishes up an experimental fish ladder at Itaipu Reservoir: fish size, reproductive stage and taxonomic group influences. Neotropical Ichthyology, 5: 215-222.

Gehrke, P. C., D. M. Gilligan \& M. Barwick. 2002. Changes in fish communities of the Shoalhaven River 20 years after construction of Tallowa dam, Australia. River Research and Applications, 18: 265-286.

Godinho, A. L. \& B. Kynard. 2006. Migration and spawning of radio-tagged Zulega Prochilodus argenteus in a dammed Brazilian river. Transactions of the American Fisheries Society, 135: 811-824.

Godinho, A. L. \& B. Kynard. 2008. Migratory fishes of Brazil: life history and fish passage needs. River Research and Appliactions, 25: 702-712.

Godinho, A. L., B. Kynard \& H. P. Godinho. 2007. Migration and spawning of female surubim (Pseudoplatystoma corruscans, Pimelodidae) in the São Francisco River, Brazil. Environmental Biology of Fishes, 80: 421-433.

Godoy, M. P. 1959. Age, growth, sexual maturity, behavior, migration, tagging and transplantation of the Curimbatá (Prochilodus scrofa Steindachner, 1881) of the Mogi Guaçu River, São Paulo State, Brazil. Anais da Academia. Brasileira de. Ciências, 31: 447-477.

Hubert, W. A. \& M. C. Fabrizio. 2007. Relative abundance and Catch per Unit Effort. Pp. 279-326. In: Guy, C. S. \& M. L. Brown. (Eds). Analysis and interpretation of freshwater fisheries data. American Fisheries Society, Betheseda, Maryland, 961p.

Jackson, D. C. \& G. Marmulla. 2001. The influence of dams on river fisheries. In: Marmulla, G. (Ed.). Dams, fish and fisheries: opportunities, challenges and conflict resolution. FAO, Rome, $1-44$.

Katopodis, C. \& J. G. Williams. 2011. The development of fish passage research in a historical context. Ecological Engineering, DOI: 10.1016/j.ecoleng.2011.07.004.

Lopes, C. M. F. S. de Almeida, M. L. Orsi, S. G. de Castro-Britto, R. N. Sirol \& L. M. K. Sodré. 2007. Fish passage ladders from Canoas Complex - Paranapanema River: evaluation of genetic structure maintenance of Salminus brasiliensis (Teleostei: Characiformes). Neotropical Ichthyology, 5: 131-138.

Lopes, J. M. \& F. O. Silva. 2012. Metodologia para o planejamento, implantação, definição de objetivos e monitoramento de sistemas de transposição de peixes pela CEMIG. Pp. 17-35. In: CEMIG (Ed.). Transposição de peixes. Série Peixe Vivo, 173p.

Makrakis, S., M. C. Makrakis, R. L. Wagner, J. H. P. Dias \& L. C. Gomes. 2007. Utilization of the fish ladder at the Engenheiro Sérgio Motta Dam, Brazil, by long distance migrating potamodromous species. Neotropical Ichthyology, 5: 197-204.

Makrakis, S., L. E. Miranda, L. C. Gomes, M. C. Makrakis \& H. M. F. Junior. 2011. Ascent of neotropical migratory fish in the Itaipu reservoir fish pass. River Research and Applications, 27: 511-519.

Okada, E. K., A. A. Agostinho \& L. C. Gomes. 2005. Spatial and temporal gradients in artisanal fisheries of a large Neotropical reservoir, the Itaipu Reservoir, Brazil. Canadian Journal of Fisheries and Aquatic Sciences 62: 714-724.
Oldani, N. O., C. R. M. Baigún, J. M. Nestler \& R. A. Goodwin. 2007. Is fish passage technology saving fish resources in the lower La Plata River basin? Neotropical Ichthyology, 5: 89-102.

Pelicice, F. M. \& A. A. Agostinho. 2007. Fish passage facilities as ecological traps in large neotropical rivers. Conservation Biology, 22: $180-188$.

Pompeu, P. S. \& C. B. Martinez. 2005. Estabelecimento da regra operativa de um mecanismo de transposição de peixes do tipo elevador com caminhão-tanque. Revista Brasileira de Recursos Hídricos, 10: 31-42.

Pompeu, P. S. \& C. B. Martinez. 2007. Efficiency and selectivity of a trap and truck fiah passage system in Brazil. Neotropical Ichthyology, 5: 169-176.

Pompeu, P. S., A. A. Agostinho \& F. M. Pelicice. 2012. Existing and future challenges: the concept of successful fish passage in South America. River Research and Applications, 28: 504-512.

Roscoe, D. W. \& S. G. Hinch. 2010. Effectiveness monitoring of fish passage facilities: historical trends, geographic patterns and future directions. Fish and Fisheries, 11: 12-33.

Santos, H. A., P. S. Pompeu \& C. B. Martinez. 2007. Swimming performance of the migratory Neotropical fish Leporinus reinhardti (Characiformes: Anostomidae). Neotropical Ichthyology, 5: 139-146.

Sato, Y. \& H. P. Godinho. 2003. Migratory fishes of the São Francisco River. In: Carolsfeld, J., B. Harvey, C. Ross \& A. Baer (Eds). Migratory fishes of South America: Biology, fisheries and conservation status. Ottawa: World Fisheries Trust, 371p.

Schilt, C. R. 2002. Natural history in an unnatural environment: can we help fish to help themselves? Bioacoustics, 12: 310-313.

Schilt, C. R. 2007. Developing fish passage and protection at hydropower dams. Applied Animal Behaviour Science, 104: 295-325

Silva, L. G. M. 2004. Migração de mandis-amarelos-amarelos Pimelodus maculatus e curimbas Prochilodus lineatus no rio Grande, bacia do Alto Paraná. Unpublished MSc Dissertation, Programa de Pós-graduação em Zoologia de Vertebrados, PUC Minas, Belo Horizonte. 63p.

Sokal, R. R. \& F. J. Rohlf. 1995. Biometry: the principles and practice of statistics in biological research. $3^{\text {rd }}$ Edition. W.H. Freeman and Company, New York, 887p.

StatSoft, Inc. 2011. Electronic Statistics Textbook. Tulsa, OK: StatSoft. WEB: http://www.statsoft.com/textbook/.

Viana, E. M. F., C. B. Martinez \& M. G. Marques. 2007. Mapeamento do campo de velocidades em mecanismo de transposição de peixes do tipo ranhura vertical construído na UHE de Igarapava. Revista Brasileira de Recursos Hídricos, 12: 5-16.

Viana, E. M. F., C. B. Martinez \& M. T. C. Faria. 2010. Comparação do Mapeamento do Campo de Velocidades, em Mecanismo de Transposição de Peixes do Tipo Ranhura Vertical construído na UHE de Igarapava, em modelo e protótipo. PCH Notícias \& SHP News, 47: 20-25.

Vieira, F. 2009. Distribuição, impactos ambientais e conservação da fauna de peixes da bacia do rio Doce. MGBiota, 2: 5-22.

Williams, J. G., G. Armstrong, C. Katapodis, M. Larinier \& F. Travade. 2012. Thinking like a fish: a key ingredient for development of effective fish passage facilities at river obstructions. River Research and Applications, 28: 407-417.

Submitted March 28, 2012 Accepted September 20, 2012 